\title{
Can we be all in one?
}

\author{
Maria Rita Tagliaventi ${ }^{1}$, Giacomo $\mathrm{Carli}^{2}$, Donato $\mathrm{Cutolo}^{3}$ \\ ${ }^{1}$ Department of Sociology and Business Law, Univeristy of Bologna, Italy, ${ }^{2}$ Department for \\ Strategy and Marketing, Open University, United Kingdom, ${ }^{3}$ Department of Mangement, \\ Univeristy of Bologna, Italy
}

\begin{abstract}
The pursuit of a high research performance is nowadays shared by academics internationally since it is considered to sustain national development. Generating outstanding research is an effort that can jeopardize the enactment of other academic activities and the attainment of related satisfying goals, though. While the interplay between research and other knowledge transfer activities such as patenting, spin-off creation and consulting, has been widely debated, the influence of research on academic citizenship, i.e., on the service provided by faculty to their institution and to the wider collective, has remained surprisingly in the backward of the reflection on higher education systems. This study analyzes the effect of research performance on academic citizenship in a sample of 216 Italian academics in the field of management. With the exception of research awards and international scientific collaborations, research does not emerge to significantly impact upon academic citizenship, which may account for the scarce attention devoted to this latter. Since service is necessary for all organizations, universities included, to thrive, citizenship needs to be fostered and awarded through appropriate institutional and managerial policies that are here highlighted.
\end{abstract}

Keywords: Academic citizenship; Research excellence; Business school; Performance measurement; University; Higher education. 


\section{Not Only Researchers, but Also Citizens: A Theoretical Framework}

Academics are increasingly experiencing the pressure to achieve outstanding research performance all over the world over the past decades (Pifer \& Baker, 2013; Kok \& McDonald, 2017). Academics have therefore been pursuing publications in A-ranked journals, a high number of citations, and a significant H-index (Agarwal et al., 2016). At the same time, although not so straightforwardly as for research, faculty are expected to perform a variety of additional knowledge transfer tasks, among which teaching, patenting, spin-off creation, dissemination, consulting services (Rossi \& Rosli, 2015; Salter, Salandra, \& Walker, 2017). Whether and how to reach a challenging balance between these heterogeneous academic duties has been largely debated in the literature, also tapping into possible trade-offs existing among them (e.g., Hattie \& Marsh, 1996; Salter et al., 2017).

Faculty, however, are not only required to engage in knowledge transfer activities: they must also contribute to the ordinary functioning of their institution. This implies that they have to enact academic citizenship, which has been almost neglected in the reflection on higher education. The meaning of academic citizenship is far from being agreed on. While some studies liken academic citizenship to organizational citizenship behavior in general, i.e., to voluntary behaviors carried out for the sake of the organization without explicit reward expectations (e.g., Lawrence, Ott, \& Bell, 2012), the still scant reflection on this topic questions its voluntary nature, while underlining its impact not only on the university, but also on the wider collective (Thompson, Constantineau, \& Fallis, 2005; Macfarlane, 2011). Academic citizenship can in fact be defined as the service that academics provide to their employing organization-e.g., sitting on committees and Senate, directing programs, etc., to the scientific community to which they belong-e.g., acting as journal reviewer or editor, and the society in which they are embedded - e.g., representing the university on the media, participating in other institutions' boards. By embracing a view of academic citizenship that extends beyond the usual university boundaries, the relevance of higher education as core institutional player is revamped (Nørgård \& Bengtsen, 2016). Accordingly, the university is no longer an 'ivory tower' that produces knowledge accessible and important only among scholars, but a 'placeful' institution able to share knowledge with a variety of other institutions and to affect societal policies (e.g., Nørgård \& Bengtsen, 2016).

If the recognition of academic citizenship as a faculty obligation resonates with most faculty's experience, the comprehension of what factors foster or hamper its enactment, alongside its relationship with research excellence, still cry out for theoretical and empirical works. This study has the very goal of fleshing out the levers of academic citizenship and its interplay with research performance. 
Individual and organizational characteristics likely affect faculty engagement in academic citizenship (Vogelgesang, Denson, \& Jayakumar, 2010). Among individual features, former behavioral patterns influence the actual enactment of academic citizenship. Individuals in fact tend to stick to and reiterate behaviors in which they have achieved positive outcomes, since these latter are a source of self-enhancement and self-continuity, and for the same reason they tend to refrain from tasks and behaviors in which they have not exceled before ( Carli, Tagliaventi, \& Cutolo, 2018). Along this line of reasoning, research-focused effort, expressed through previous research performance, previous involvement in visiting scholarship, previous research awards, and previous network of international collaborations, reduces the willingness to undertake service as it is a diversion from consolidated courses of action. Conversely, experience with service tends to be repeated over time, as adequate expertise has already been developed. The following hypotheses can therefore be formulated:

Hypothesis 1a: Previous research-oriented behaviors are negatively related to successive academic citizenship.

Hypothesis 1b: Previous academic citizenship is positively related to successive academic citizenship.

Contextual factors can impact upon the performance of academic citizenship, too. A strong orientation to research both at the upper (university) and lower (department) levels implitly or explicitly communicates that academic citizenship is irrelevant, if not only detrimentals since it subtracts attention and time from research (Macfarlane, 2007, 2011). This relationship can be posited as follows:

Hypothesis 2a: Previous university orientation to research is negatively related to successive academic citizenship.

Hypothesis 2b: Previous departement orientation to research is negatively related to successive academic citizenship.

Another contextual factors that can influence the carrying out of academic citizenship is university size. The larger the university size in fact, the weaker the tie that links academics to its hosting institution (Macfarlane, 2007). In big organizations, the perception of the importance of one's own contribution to the overall success is lessened and individuals withdraw from behaviors that benefit the collective rather that themselves. Consequently, the relationship between university dimension and academic citizenship can be formulated as below:

Hypothesis 3: University size is negatively related to academic citizenship. 


\section{Data and Method}

To test our hypotheses, we collected data on academics in Italy, where a higher education reform introduced a promotion system focused on research excellence in 2010 and connected university funding to research outputs. Our dataset is composed by 216 academics in management with different positions. We collected ther publications related to two different evaluation rounds, before the reform (2004-2010) and after (2011-2013) using Scopus database. We also collected their full CVs from the Italian accreditation database and from university websites. Academic citizenship activities were codified in three different variables, Institutional, Public and Discipline-based service, counting for each categories the number of engagements per year. The full list of variables is reported in Table 1.

Given that academic citizenship measures are overdispersed and not normally distributed count variables, Poisson and negative binomial models were compared in testing the effect of independent individual and contextual factors measured in 2004-2010 on the dependent variables of academic citizenship (Long, 1997). The likelihood ratio tests suggested that a negative binomial regression was preferable to a Poisson model. Robust estimators were used to control for mild violations of assumptions (Cameron \& Trivedi, 2013).

\section{Findings}

Findigs are reported in Table 2, which presents the incidence rate ratios, indicating how many times the dependent variable would increase for a unit change in the independent variable.

Hp.1a was not strongly supported: the effect of past research excellence on the three forms of academic citizenship was not significant, but Research Grants had a significant effect only on public service (17\%). Conversely, Hp1b found full support: the three forms of academic citizenship are influenced by previous experience of the same type. For instance, a previous commitment in public service increases the likelihood of engaging in academic service by $24 \%$. Moreover, discipline-based service had a partially significant effect on institutional citizenship while past institutional service positively affected public service (4\%).

Scarce support was found for Hp.2a showing that university ranking negatively influences only public service activities, while the effect on other types of academic citizenship is not significant. The negative effect of the quality of the department on academic citizenship (Hp. 2b) was not supported in our model. Similarly, Hp.3 on university size was not confirmed. The controls on academic role showed that assistant and associate professors are more dedicated to institutional service, respectively $159 \%$ and $135 \%$, than full professors, 
and assistant professors are more focused on discipline-based service than full professors (97\%). Gender differences affected only public service with a stronger impact (101\%) of being male.

\section{Conclusion}

Academic citizenship appears to be the missing kernel in the lively debate on higher education systems, which has extensively delved into the interplay between research and teaching and between research and teaching (Hattie \& Marsh, 1996; Lawrence et al., 2012). Apart from the influence exerted by research awards and collaboration, this analysis does not disclose a relevant substitution or complementariety effect between research and service (Landry, Saïhi, Amara, \& Ouimet, 2010).

The scant attention devoted to academic citizenship in higher education studies thus far can be traced back to the very lack of a clear relationship between this latter and the publishing effort that emerges from our analysis. Universities, like any other organizations, however, need citizenship behaviors to function effectively. It is high time that more empirical work and theoretical reflection address this topic, exploring further its relationship with a variety of knowledge transfer activities in different settings. Future studies could adopt both qualitative research based on interviews and surveys to shed light on the motivation underpinning faculty choices. In parallel, though, policy makers and university management should explicitly communicate the value of academic citizenship by including it in performance measurement systems (Vogelgesang et al., 2010). The perception that being good servants of an institution by providing service inside and outside its boundaries may not only be uninfluential, but even run counter individual assessment in career advancement has to be taken seriously into account and contrasted. Some scholars have in fact voiced the concern that playing out service be detrimental to academic careers, as it is deemed to be a sign of the incapacity to drive time and resources towards the gist of the academic profession, i.e., research (Thompson et al., 2005; Knights \& Clarke, 2014). A revision of the actual appraisal system of faculty worth is evoked, and promoting studies on academic citizenship will reinforce this call, likely testifying to what most members of contemporary universities already know, i.e., that only hardly can each of us be excellent in all fields - be all in one-but a carefully designed diversification of excellence across individuals can render organizations excellent as a whole. 
Table 1. Measures.

\begin{tabular}{|c|c|c|c|}
\hline Variable & Description & Reference & Source \\
\hline $\begin{array}{l}\text { Previous high- } \\
\text { quality research }\end{array}$ & $\begin{array}{l}\text { Count of the scientific contributions reported in } \\
\text { Scopus per year }\end{array}$ & $\begin{array}{l}\text { Carli et al. } \\
(2018)\end{array}$ & Scopus \\
\hline Research awards & $\begin{array}{l}\text { Binary variable coded as } 1 \text { if the scholar received } \\
\text { a scientific award }\end{array}$ & $\begin{array}{l}\text { Agarwal et } \\
\text { al. (2016) }\end{array}$ & CVs \\
\hline $\begin{array}{l}\text { Previous } \\
\text { Institutional } \\
\text { service1 }\end{array}$ & $\begin{array}{l}\text { Count of activities and roles in university boards } \\
\text { and committees per year }\end{array}$ & $\begin{array}{l}\text { Macfarlane } \\
(2007,2011)\end{array}$ & CVs \\
\hline $\begin{array}{l}\text { Previous Public } \\
\text { service1 }\end{array}$ & $\begin{array}{l}\text { Count of activities and roles in public bodies and } \\
\text { non-profit organizations per year }\end{array}$ & $\begin{array}{l}\text { Macfarlane } \\
(2007,2011)\end{array}$ & $\mathrm{CVs}$ \\
\hline $\begin{array}{l}\text { Previous } \\
\text { Discipline-based } \\
\text { service1 }\end{array}$ & $\begin{array}{l}\text { Count of peer reviewer or editorial board roles and } \\
\text { scientific conference board membership per year }\end{array}$ & $\begin{array}{l}\text { Macfarlane } \\
(2007,2011)\end{array}$ & CVs \\
\hline $\begin{array}{l}\text { International } \\
\text { mobility }\end{array}$ & $\begin{array}{l}\text { Binary variable coded as } 1 \text { if the academic did a } \\
\text { visiting period }\end{array}$ & $\begin{array}{l}\text { Jonkers and } \\
\text { Cruz-Castro } \\
(2013)\end{array}$ & CVs \\
\hline $\begin{array}{l}\text { International } \\
\text { collaboration }\end{array}$ & $\begin{array}{l}\text { Number of international co-authors of all the } \\
\text { publications published }\end{array}$ & $\begin{array}{l}\text { Carli et al. } \\
(2018)\end{array}$ & CVs \\
\hline University ranking & $\begin{array}{l}\text { Universities' scores in the 2004-2010 Research } \\
\text { Quality Assessment }\end{array}$ & $\begin{array}{l}\text { Salter et al. } \\
(2017)\end{array}$ & Reports \\
\hline Department ranking & $\begin{array}{l}\text { Departments' scores in the 2004-2010 Research } \\
\text { Quality Assessment }\end{array}$ & $\begin{array}{l}\text { Salter et al. } \\
(2017)\end{array}$ & Reports ${ }^{2}$ \\
\hline $\begin{array}{l}\text { University } \\
\text { dimension }\end{array}$ & $\begin{array}{l}\text { Categorical variable for small ( }<10,000 \text { students), } \\
\text { medium (between 10,000 and } 20,000 \text { students) } \\
\text { and big universities ( }>20,000 \text { students) }\end{array}$ & $\begin{array}{l}\text { Salter et al. } \\
(2017)\end{array}$ & Reports $^{2}$ \\
\hline Academic position & $\begin{array}{l}\text { Binary variables for Assistant, Associate and Full } \\
\text { Professor positions }\end{array}$ & $\begin{array}{l}\text { Carli et al. } \\
(2018)\end{array}$ & CVs \\
\hline Gender & 1 for males and 0 for females & $\begin{array}{l}\text { Carli et al. } \\
\text { (2018) }\end{array}$ & CVs \\
\hline
\end{tabular}

${ }^{1}$ : calculated for 2004-2010 period. The dependent variables are calculated for 2011-2013 period with the same procedure

${ }^{2}$ : Reports from the Italian National Agency for the Evaluation of the University and of Research System 
Table 2. Negative binomial regression results for academic citizenship (Instutional, Public and Discipline-based service).

\begin{tabular}{|c|c|c|c|c|c|c|}
\hline \multirow[t]{2}{*}{ Variables } & \multicolumn{2}{|c|}{ Institutional Service } & \multicolumn{2}{|c|}{ Public Service } & \multicolumn{2}{|c|}{$\begin{array}{c}\text { Discipline-based } \\
\text { Service }\end{array}$} \\
\hline & IRR & $\begin{array}{c}\text { Robust } \\
\text { SE }\end{array}$ & IRR & $\begin{array}{l}\text { Robust } \\
\text { SE }\end{array}$ & IRR & $\begin{array}{c}\text { Robust } \\
\text { SE }\end{array}$ \\
\hline $\begin{array}{l}\text { Previous high-quality } \\
\text { research }\end{array}$ & 0.993 & 0.020 & 0.996 & 0.033 & 0.984 & 0.022 \\
\hline Research awards & 0.952 & 0.041 & $1.171 * *$ & 0.077 & 1.028 & 0.054 \\
\hline $\begin{array}{l}\text { Previous Institutional } \\
\text { service }\end{array}$ & $1.113 * * *$ & 0.013 & $1.040 * *$ & 0.019 & 0.997 & 0.014 \\
\hline Previous Public service & 0.982 & 0.015 & $1.239 * * *$ & 0.037 & $0.958 * *$ & 0.021 \\
\hline $\begin{array}{l}\text { Previous Discipline- } \\
\text { based service }\end{array}$ & $1.024 *$ & 0.014 & 0.990 & 0.019 & $1.200 * * *$ & 0.029 \\
\hline International mobility & 1.274 & 0.187 & 1.076 & 0.282 & 1.320 & 0.239 \\
\hline $\begin{array}{l}\text { International } \\
\text { collaboration }\end{array}$ & 0.986 & 0.034 & 0.981 & 0.061 & $1.074 *$ & 0.042 \\
\hline University ranking & 0.338 & 0.303 & $0.030 * *$ & 0.048 & 0.531 & 0.597 \\
\hline Department ranking & 0.482 & 0.335 & 0.462 & 0.520 & 0.331 & 0.262 \\
\hline \multicolumn{7}{|l|}{ University dimension } \\
\hline $\begin{array}{l}\text { Medium (between } \\
10.000 \text { and } 20.000 \\
\text { students) }\end{array}$ & 1.340 & 0.276 & 0.559 & 0.224 & 1.019 & 0.265 \\
\hline $\begin{array}{l}\text { Large (more than } \\
10.000 \text { students) }\end{array}$ & 1.169 & 0.215 & 0.783 & 0.280 & 1.000 & 0.237 \\
\hline \multicolumn{7}{|l|}{ Academic position } \\
\hline Assistant professor & $2.590 * * *$ & 0.541 & 1.329 & 0.423 & $1.969 * * *$ & 0.507 \\
\hline Associate professor & $2.349 * * *$ & 0.496 & 1.061 & 0.335 & 1.567 & 0.425 \\
\hline Gender (Male) & 1.138 & 0.165 & $2.009 * * *$ & 0.480 & 1.154 & 0.206 \\
\hline Costant & 1.051 & 0.349 & 1.329 & 0.779 & 1.156 & 0.459 \\
\hline $\ln ($ alpha $)$ & -0.676 & 0.231 & 0.388 & 0.211 & 0.127 & 0.167 \\
\hline Observations & 216 & & 216 & & 216 & \\
\hline Wald $\chi^{2}$ & 113.839 & & 89.694 & & 79.175 & \\
\hline Prob $>\chi^{2}$ & 0.000 & & 0.000 & & 0.000 & \\
\hline Log-likelihood & -470.326 & & -307.726 & & -447.876 & \\
\hline Cragg \& Uhler's R2 & 0.413 & & 0.353 & & 0.310 & \\
\hline
\end{tabular}




\section{References}

Agarwal, A., Durairajanayagam, D., Tatagari, S., Esteves, S., Harlev, A., Henkel, R., ... Bashiri, A. (2016). Bibliometrics: tracking research impact by selecting the appropriate metrics. Asian Journal of Andrology, 18(2), 296.

Cameron, A. C., \& Trivedi, P. K. (2013). Regression Analysis of Count Data (2 edition). Cambridge ; New York, NY: Cambridge University Press.

Carli, G., Tagliaventi, M. R., \& Cutolo, D. (2018). One size does not fit all: the influence of individual and contextual factors on research excellence in academia. Studies in Higher Education, 1-19. https://doi.org/10.1080/03075079.2018.1466873

Hattie, J., \& Marsh, H. W. (1996). The Relationship Between Research and Teaching: A Meta-Analysis. Review of Educational Research, 66(4), 507-542.

Jonkers, K., \& Cruz-Castro, L. (2013). Research upon return: The effect of international mobility on scientific ties, production and impact. Research Policy, 42(8), 1366-1377.

Knights, D., \& Clarke, C. A. (2014). It's a Bittersweet Symphony, this Life: Fragile Academic Selves and Insecure Identities at Work. Organization Studies, 35(3), 335357. https://doi.org/10.1177/0170840613508396

Kok, S. K., \& McDonald, C. (2017). Underpinning excellence in higher education - an investigation into the leadership, governance and management behaviours of highperforming academic departments. Studies in Higher Education, 42(2), 210-231. https://doi.org/10.1080/03075079.2015.1036849

Lawrence, J., Ott, M., \& Bell, A. (2012). Faculty Organizational Commitment and Citizenship. Research in Higher Education, 53(3), 325-352. https://doi.org/10.1007/s11162-011-9230-7

Long, J. S. (1997). Regression Models for Categorical and Limited Dependent Variables (1 edition). Thousand Oaks: SAGE Publications, Inc.

Macfarlane, B. (2007). Defining and Rewarding Academic Citizenship: The implications for university promotions policy. Journal of Higher Education Policy and Management, 29(3), 261-273. https://doi.org/10.1080/13600800701457863

Macfarlane, B. (2011). The Morphing of Academic Practice: Unbundling and the Rise of the Para-academic: The Morphing of Academic Practice. Higher Education Quarterly, 65(1), 59-73. https://doi.org/10.1111/j.1468-2273.2010.00467.x

Nørgård, R. T., \& Bengtsen, S. S. E. (2016). Academic citizenship beyond the campus: a call for the placeful university. Higher Education Research \& Development, 35(1), 416. https://doi.org/10.1080/07294360.2015.1131669

Pifer, M., \& Baker, V. (2013). Identity as a Theoretical Construct in Research about Academic Careers. In J. Huisman \& M. Tight (Eds.), International Perspectives on Higher Education Research (Vol. 9, pp. 115-132). Emerald Group Publishing Limited. https://doi.org/10.1108/S1479-3628(2013)0000009010

Rossi, F., \& Rosli, A. (2015). Indicators of university-industry knowledge transfer performance and their implications for universities: evidence from the United Kingdom. Studies in Higher Education, 40(10), 1970-1991. 
Salter, A., Salandra, R., \& Walker, J. (2017). Exploring preferences for impact versus publications among UK business and management academics. Research Policy, 46(10), 1769-1782. https://doi.org/10.1016/j.respol.2017.08.005

Thompson, P., Constantineau, P., \& Fallis, G. (2005). Academic Citizenship: An Academic Colleagues' Working Paper. Journal of Academic Ethics, 3(2-4), 127-142.

Vogelgesang, L. J., Denson, N., \& Jayakumar, U. M. (2010). What Determines FacultyEngaged Scholarship? The Review of Higher Education, 33(4), 437-472. 